INTERNATIONAL JOURNALOF
WWW.CIKD.CA
ORGANIZATIOATIONAL
WEADERSHIP

\title{
Eyeing at Eastern Philosophy for Business Leadership Model
}

\author{
Khurram Ellahi Khan $^{1 *}$, Omar Khalid Bhatti², Sadaf Kashif ${ }^{3}$ \\ ${ }^{1 *}$ Department of Business Studies Pakistan Institute of Development Economics, Islamabad Pakistan \\ ${ }^{2}$ School of Business Istanbul Medipol University, Istanbul Turkey \& Department of \\ Business Administration Iqra University Islamabad Campus Pakistan \\ ${ }^{3}$ Department of Business Administration Iqra university Islamabad Campus Pakistan
}

\section{Keywords: \\ Critical thinking, Eastern thinking model, Alternative thinking, Business leadership, Social psychology}

\section{Received}

18July 2021

Received in revised form

17 August 2021

Accepted

19August 2021

*Correspondence:

khurramellahi@pide.org.pk

\begin{abstract}
Leadership is both an art and a skill. As a skill, it requires the practical ability of an individual, group, or organization to lead, influence, and guide other individuals. As an art, leadership requires the art of motivating a group of people to act unanimously toward achieving a common goal. In a business setting, this can guide employees with a strategy to meet the company's needs. Leadership has widely been studied from the Western perspective; however, this study focuses on exploring leadership from the eastern perspective. There is a certain hegemony of Western leadership ideas, which are not aligned with oriental cultures and workplaces. Moreover, this study explores how leadership is defined, evolved, and how the Western school of thought has solely influenced it. To explore the concept of leadership, a qualitative approach was taken. Qualitative open-ended fifteen interviews were conducted with theorists and practitioners of management and business studies from three nationalities i.e. Pakistan, Turkey, and Malaysia. The findings highlight that leadership literature stems from Western values, which is incongruent with Eastern literature and wisdom and specifically not aligned with indigenous thoughts of Pakistan, Turkey, and Malaysia. Respondents considered it another form of hegemony and urged for pacing up critical studies in the realm of leadership. Respondents also added that if more studies are taken into account from Eastern cultures, more avenues could be opened to address the dilemmas in management sciences.
\end{abstract}

The phenomenon of leadership has captivated research scholars, political scientists, fiction writers, and psychologists since antiquity (Daft, 2014; Greenleaf, 1978; Grisham, 2006; Messick \& Kramer, 2004). The definition ofeffective leadership over the years has evolved from different and diversified sources. Stogdill (1974, p.7) vowed that "we have as many 
definitions of leadership as many have tried to define it". Interestingly, scholars and practitioner still date are in search of a universal definition for this significant construct (Day, 2014; Gordon \&Yukl, 2004). Diversified approaches have been introduced to elucidate the complexities in processes of leadership (Day \& Antonakis, 2012). Reasonably, it is apparent that the literature (Hunt \& Dodge, 2000; Metcalf \& Ben, 2013; Northouse, 2018; Stogdill, 1975; Van Seters \& Field, 1990) displays an evolution in understanding the phenomena of leadership, yet no universal interpretation has been established. Daft (2014) similarly affirmed that leadership phenomena are in a state of continuous evolution and, importantly, require further investigation. Den Hartog and Dickson (2004) confirm that practitioners should not use cookie-cut leadership models in different environmental settings. Turnbull (2011) advocates that sustainable values are overlooked in leadership models that stem out of Western philosophy. Thus, leadership, as understood, is a Western understanding of this phenomenon.

However, even in the Western paradigm, new dawn of leadership theories is visible. Leadership in the West is aligning more towards moral and authentic leadership models. For the volatile, uncertain, complex, and ambiguous business world around, a study of Deloitte (2016) suggested that leadership at the workplace has to reengineer for modern needs. Similarly, Giles (2016) conducted a survey of more than 190 leaders from 15 countries and found ethical concern as one key competence for future leaders. Another study, which took place in five European countries, reflected that ethics and concern for followers are critical competencies expected from the leaders (Iordanoglou, Tsakarestou, Tsene, \& Leandros, 2014). All these studies and their findings have a reason as the role of business is evolving in the Western world. Earlier businesses were assumed to be profit-reaping entities. However, Kiker, Callahan and Kiker (2019) emphasized that now there is a demand to create a balance between profit and ethics. Its implications are getting visible on leadership styles. Hoch, Bommer, andDulebohn (2018) associate this shift because of numerous corporate scandals that appeared over time. They highlighted the numbers that reflect a clear shift towards moral/ethical leadership styles. In a period of thirteen years, starting from 1980, 2090 results were shown for the ethical style of leadership. However, in subsequent thirteen years, the number jumped to 16200. Similarly, a huge shift was observed for servant leadership; also, a six hundred percent increase was seen in the period of thirteen years from 2003 onward.

The number of searches grew for the servant leadership while Western researchers had ideas like transformational leaders in their literature. The transformational leadership style was exhausting as there was no specific hint of the ethical dimension (Bass \& Riggio, 2006). Recently, Hoch, Bommer, and Dulebohn (2018) found that transformational leadership overlaps with authentic and ethical leadership styles; yet servant leadership has conceptual distinctiveness from transformational leadership. Gandolfi and Stone (2018) elaborated on three major reasons the world is opening up for new leadership models. Primarily, they highlighted the decadence in morality that can be observed in business news. Hence, in the last ten years, research and practice have shifted to the world of servant leadership. As the West finds itself caught in a quagmire of leadership dilemmas, they explore high moral leadership styles. In his work, Boddy (2011, p. 256) asserted that dark leadership is responsible for a crisis that emerged in global finance in 2008. Mitchell (2020) again highlighted that it is time to unveil dark leadership traits, so severe corporate crimes could be 
averted. Psychopaths or snakes in suits have changed the conversation of leadership in the West. Thus, apart from research, the servant view of leadership is gaining momentum in practice.

Ethical and moral dilemmas were just one reason in the West to transform the leadership style from self-serving leaders to serving leaders, as covid-19 pandemic hit the world, while old school organizations compromised on people, other companies with ethical leaders compromised on numbers to save the employees (Coetzer, 2020). Neale (2020) stressed that it is important to have servant leaders in the organizations due to covid-19 as pandemic has changed the way the world operates, and it needs more responsible leaders than ever.

West is opening up for eastern philosophies and practices. Western leaders' lack of selfawareness and mindfulness has only exposed them to selfishness and external rewards (Silverthorne, 2010). Thus, efforts of blending Western leadership with practices of the east are on the way. Silverthorne (2010) referred to ideas like Mindful leadership; such ideas are opening up the debate of having self-aware leaders that are continuously in the process of introspection. For them, the world of reward is beyond money and power. This need had been in debate even in the 90s when scholars challenged the thought of "West is Best". Especially in the realm of leadership, scholars (Blunt \& Jonnes, 1997) discussed the limits of Western leadership. Thus, we are looking at the extraordinary attention of scholars in Servant Leadership, Spiritual Leadership, etc., which are primarily rooting in Eastern philosophies.

However, over the years, the management studies point out that mainstream leadership theories and models stem out of Western expectations (Adler et al., 2007; Antonakis \& Day, 2017; Blunt \& Jones, 1997; Day et al., 2014; Dinh et al., 2014; Rosenbach, 2018). Whereas there is something to be called management across the world, but it changes its meaning as per the culture (Adler, 1983; Hofstede, 1980). Certainly, Cultures are diverse, and each holds a different meaning and significance of constructs like; success, motivation, satisfaction, engagement, and so forth (Bhatti et al., 2016). This debate and argument further escalate as the national culture of one country varies from the other, hence, making it essential to reexamine the leadership construct (Dickson et al., 2012). National culture plays an important role in making leaders be more effective and efficient. Some of the traits and behaviors are universal, but new and, original values emerge in line with the national culture (Hartog\& Dickson, 2004).

Human nature is unique as per Hofstede's work, but culture is learnt, and it changes the expectations of its denizen (Hofstede et al., 2010). Geeraert (2018) acknowledged that a greater understanding of culture demands a change in appreciating the very foundation of psychology. Dilemmas of management science may find different approaches as solution in diversified cultures. Therefore, expectations of the right answer may vary as per the cultural need. Hofstede (1993) further identified that management is an American term. Yet, the management practices in other parts of the world may differ from what is considered standard or customary in Management Science. Thus, each culture may interpret/translate the major domains of management sciences as per their cultural desires.

Looking at the oriental part of the world, Porter et al. (2000) reviewed Japanese Management styles, which were opted by Japanese thinkers after Second World War. The Japanese approach gave their economy a lot of recoveries, and their organizations started performing well. On the other hand, US companies adopted Japanese practices by title Theory 
Z (Barkema et al., 2015; Beechler \& Yang, 1994; England, 1983). Yet, no substantial difference was seen in the productivity and performance of the US companies due to incongruence between Japanese and US culture (Alzadjali, 2009). Furthermore, Law et al. (2016) affirmed the strong influence of Sun Tzu on Chinese corporate leadership. This can be observed with the existing influence of Sun Tzu philosophy on Chinese corporate leaders (Law et al., 2016). Chinese corporate leaders have a deep understanding of the values forwarded by Sun Tzu in Art of war (Wang, 2017), helping them be effective leaders in the Chinese context. In contrast, considering the mindset of Malaysians, which is encapsulated in budi complex, Budi embodies "all the virtues ranked in the system of values of the society... the structure of budi is composed of honorable qualities such as murahhati (generosity), hormat (respect), ikhlas (sincerity), mulia (righteousness), timbang-rasa (consideration) malu (feelings of shame at the collective level) and segan (feeling of shame at the individual level)" (Storz, 1999 p.119). Malaysian's budiis such that they focus more on the business's social and relational aspect than transactional aspect (Storz, 1999). The aforementioned studies and work of Chen and Miller (2011) highlight that culture plays a vital role in the success of managerial practices. That phenomenon of leadership is not universal (House et al., 2004). Rather it molds and takes shape as per the need of locale. That signifies the need to incubate ideas from diversified communities and ideologies.

Feyerabend (1995), in view to the same, criticizes the Western monotheistic way of understanding humanity. So much so, Anderson et al. (2017) argued that there is a need to reconsider the existing leadership theories. They argue that leadership style must match the culture and behaviours of the employees they are trying to influence. Due to this, the idea of leadership is at crossroads (Tucker, 2013), trying to meet the cultural and individual demands of the followers. The culture and background of followers affect leadership's values (Ogbonna \& Harris, 2000). Apart from not finding a universal leadership style that matches a diversified culture, Feyerabend (1995, p. 143) requires insight into current leadership models in Eastern cultures. Culture may demand leaders to adapt the values of followers, however, the Feyerabendian philosophy further challenges the current understanding of leadership by affirming that; "is there any one way of science, there are many ways before they were ruined by the Western way of thinking" (Feyerabend, 1995, p. 143). Likewise, Axelrod (2010) and Zhang et al. (2012) reaffirm that learning from local wisdom may assist leaders in following the right direction.

Harkiolakis et al. (2017) forwarded the notion "to look backwards to move forward" empowering cultures to look back into their classics to guide management science for the future. Past studies (Adler et al., 2007; Antonakis \& Day, 2017; Blunt \& Jones, 1997; Day, 2014; Dinh et al., 2014; Dinh \& Lord, 2012; Hofstede, 1980; House et al., 2002; Rosenbach, 2018; Storey, 2016) insist that every culture and tradition may look into their archive of scholars and philosophers to understand and develop the idea of leadership. Zaccaro (2014) and Prastacos et al. (2013) argue that these great ideas of leadership impending from different cultures (For example, Greek, Chinese or Indian) hold great significance for modern leaders. Similarly, Wang (2017) and Law et al. (2016) have empirically assessed the influence of traditional Chinese philosophy on today's business leaders and, subsequently, have showcased that managers use a lot of techniques from indigenous philosophy. 
As a result, thoughts from the subcontinent culture in view of leadership, specifically from the colonial era, maybe applied (Cappelli et al., 2010; Munshi, 2010; Nayak, 2018; Selvarajah et al., 2014). Sulaiman et al. (2013) and Mohsen (2007) affirm that the overall philosophy of the Islamic worldview stands contrary to the current understanding of human nature by the West. Therefore, this adds to the dire need to explore traditional wisdom to address the question of leadership (Harkiolakis et al., 2017; Zaccaro, 2014). At the same time, Chen and Miller (2011) appropriated the work from traditional classical philosophy to draw lessons for leadership. However, their study focuses more on the Chinese and Confucian wisdom for business leaders.

Summing up the aforesaid, there is a need to understand the phenomenon of leadership other than that of the Western perspective, specifically how leadership in oriental culture is defined, its evolution, how it is being influenced by the Western school of thought, and if oriental culture (Indo-Muslim culture) can provide us with an alternative understanding of leadership phenomena. Notably, the study focuses on local thoughts of thinkers and philosophers addressing the phenomenon of leadership; specifically, thoughts emerging from oriental thinkers as signified by Turnbull (2011).

The present study would unveil the indigenous leadership model resting on the foundations of oriental cultures and philosophy. The study would forward and propose an alternate to conventional leadership models in practice. Indigenous and oriental leadership models would open new avenues for researchers to dig deep into thoughts from unsung cultures of the world. Thus, a more holistic understanding of leadership would establish in the future once leadership philosophy is archived from unheard cultures.

\section{Literature Review}

Wheatley (2011) highlighted how the overall understanding of leadership evolved in congruence with the changes in the science of physics. Reflecting that idea of business leadership has been learning from social and natural sciences. The evolution in the idea of leadership referred earlier (Daft, 2014; Northouse, 2018) was not only motivated by changes in social science, but leadership has also considerably learned from natural science. However, more of our understanding comes from W.E.I.R.D (from Western, Educated, Industrialized, Rich and Democratic) subjects (Henrich, Heine, \& Norenzayan, 2010) when data is to be collected on any social-psychology phenomenon. Our understanding of modern human beings relies on subjects coming from Western, Educated, Industrialized, Rich, and Democratic populations (Lilienfeld \& Waldman, 2017).

\section{Conventional Ideas of Leadership and its Evolution}

As a key universal activity, leadership has been extensively practiced by men in general (Bass, 2008). Primary work on leadership started with Great Man theories adopting the belief that great leaders are born. The idea was forwarded by Carlyle (1993) that leaders are like heroes who influence their community. Evidence was available in religion, governments, and warfare (Gehring, 2007; Spector, 2016). The alleged notion later shaped the trait theory of leadership, finding that leaders can be distinguished from non-leaders based on different traits (Colbert et al., 2012; Wyatt \& Silvester, 2018). The theory affirmed that leaders have traits that differentiate and distinguish them from non-leaders Skepticism was raised against the trait theory of leadership (Day \& Zacacaro, 2007) as no set of universal traits could be found 
for leaders (Winston, 2018). Researchers moved their attention to the behaviors of the leaders. Instead of knowing who is a leader? Attention was given to what a leader does (Daft, 2014). On the other hand, trait and behavioral leadership models were not taking account of situational variables (Gardner et al., 2010). Leaders have to tailor their behavior as per the need of the situation (Thompson \& Glas $\varnothing, 2018$ ). Leaders are constantly interacting with the environment. Hence, researchers moved their attention to contingency theories of leadership (Fieldler, 2006). Subsequently, situational leadership theory, idea of influence theories emerged, in which researchers observed the process of influence between leaders and followers. Influence theories gave room to the idea of charismatic leadership while stressing that leadership is not about formal position but it is about inspiring others (Lowe et al., 2013). Phenomenon of leadership further evolved into a relational aspect. Relational theories consider leadership a relational process where everyone contributes their part to achieve the goal (Ilies, Nahrgang, \& Morgeson, 2007; Li et al., 2017). Unorthodox idea that emerged in relational theories is servant leadership (Greenleaf, 2007). Greenleaf conceived the idea of leader "who is servant first" by reading a novel of Herman Hesse "The Journey to the East" (Hesse, 2003). Reading the text of Herman Hesse, Greenleaf envisages the idea of servant leadership. Spears (2010) evaluated that the Top 100 best companies rated by Fortune Magazine are making servant leadership as part of their corporate culture. Though this is paradoxical even to write servant and leader together (Neubert et al., 2016), as a quantum of knowledge is expanding and knowledge is becoming more accessible, employees need facilitation and serving from leader rather than direction. Thus, ideas like servant leadership invite researchers to use unorthodox, local, or indigenous knowledge forms to find new effective leadership models.

\section{Leadership Ideas from Unorthodox Avenues}

Scholars and researchers have been exploring unheard avenues to learn more about leadership as Greenleaf (1997) was inspired by the fiction work of Herman Hesse to conceptualize the idea of Servant Leadership. Similarly, Sloan (2016) has used the principles from Art of War, which can guide leaders. Zaccaro (2014) has also found Art of War as a guiding tool for leaders of the $21^{\text {st }}$ century. Specifically, when a leader has to fulfill the role of leader-warrior, Sun Tzu guides the leaders in strategic management and risk-taking. The study of Wang (2017) has also established the link between social justice leadership and how it can be checked with fundamentals given by Sun Tzu. Wang et al. (2017) have also highlighted that Chinese corporate leaders have a deeper understanding of Sun Tzu and practice learning from it. The work of Sun Tzu \& Herman Hesse has been used to establish leadership models; however, findings for leadership have been discussed by Zaccaro (2014) that came from myths and even legendary figures.

\section{Method}

The current study is a precursor of a larger study to draw a leadership model of oriental roots. This study is qualitative, so the views of scholars and practitioners of leadership can be explored. Interviews were conducted in Pakistan, Turkey, and Malaysia regarding the incoherence of Western understanding of leadership. Semi-structured interviews are conducted to capture the respondents' views on leadership and how Western expectations are associated with it. Myers (2013) and Bhatti et al. (2016) assert that semi-structured interviews 
are an important technique to decipher the less explored phenomenon. The current area has the probability that new questions can emerge during a conversation. However, questions will revolve around the following areas. Questions in the interview focused on major areas of the study - leadership, evolution in leadership understanding, leadership per industrial and capitalist demand, critical management studies, culture and leadership, Western hegemony of leadership understanding, way forward for oriental cultures to find a new model of leadership. The member-checking method of validation (Creswell, 2014) was adopted to validate the interviews. Transcribed interviews along with generated themes were taken back to the participants for respondents' validation. As a result, participants of the study were satisfied with transcribed interviews and themes.

We used the inductive coding method for the current study. We explored the phenomenon of leadership from a new dimension; hence initial codes were extracted from the raw data that was transcribed. Thus, open coding technique is used so data can reveal the themes of the study (Kuckartz, 2014).

Manual method of coding is used to generate initial codes. Words matching with the essence

of current study and with higher frequency were labelled for initial codes. Initial codes were later condensed into meaningful focused codes. Initial and focused codes were shared with seven external Raters, and they verified the codes. The themes of the study emerged out of focused codes after due deliberation of the researchers.

A sample of 15 respondents from academia and industry was chosen for the current study. The purposive sampling technique was used. All respondents had their expertise in the field of leadership also have good knowledge of poets, philosophers, and scholars from the East. The demographic information of the respondents is presented in Table 1.

Table 1

Demographic Information of the Respondents

\begin{tabular}{|c|c|c|c|c|c|}
\hline S No. & Gender & Title and Organization & Nationality & Age & Work Experience \\
\hline Respondent 01 & Male & Vice Chancellor - University & Pakistan & 58 & 30 Years \\
\hline Respondent 02 & Male & Vice Chancellor - University & Turkish & 59 & 27 Years \\
\hline Respondent 03 & Male & Chairman - Research Centre & Turkish & 60 & 26 Years \\
\hline Respondent 04 & Female & Director - Academic Institute & Pakistan & 49 & 19 Years \\
\hline Respondent 05 & Female & CEO - NGO working for Academia & Malaysian & 44 & 14 Years \\
\hline Respondent 06 & Male & CEO - HR outsourcing company & Malaysian & 46 & 22 Years \\
\hline Respondent 07 & Male & Asst. Professor - University & Pakistan & 36 & 08 Years \\
\hline Respondent 08 & Male & Director - Research Centre & Malaysian & 66 & 36 Years \\
\hline Respondent 09 & Female & Asst. Professor - University & Turkish & 46 & 12 Years \\
\hline Respondent 10 & Female & Professor - University & Pakistan & 54 & 22 Years \\
\hline Respondent 11 & Female & Manager- HR Multinational & Malaysian & 47 & 17 years \\
\hline Respondent 12 & Male & Emeritus Professor - University & Turkish & 71 & 40 years \\
\hline Respondent 13 & Male & Former CEO - Multinational & Pakistan & 65 & 35 years \\
\hline Respondent 14 & Male & GM - Finance Multinational & Turkish & 47 & 22 years \\
\hline Respondent 15 & Male & Director- Research and Training Multinational & Malaysian & 55 & 29 years \\
\hline
\end{tabular}

\section{Data Collection and Analysis}

Respondents were approached for the interview, and each interview lasted for 25-30 minutes. Major questions as mentioned in methodology were asked from respondents. With the consent 
of respondents, interviews were recorded for transcribing later on. Out of 15 respondents, 10 were male and five were female.

\section{Findings and Discussions}

The present section covers the results of this exploratory study, organized in accordance with the research objective. From the interviews conducted, the following themes were extracted.

\section{Theme 1: Different Understanding of Leadership in the East}

Leadership has a different understanding in the East; since antiquity, philosophers and thinkers from the East hold a different realization of leading people. Specifically, it is inclined more towards services; In brief, it focuses on serving the follower as quoted by Respondent 1. Respondent 2 endorsing Respondent 1 affirmed that leadership, copied from West, came with different languages and understanding. The capitalistic understanding of leadership clashed with the core values of the East or oriental cultures. Eastern tenets had been more altruistic as Leadership is looked upon as taking care of the followers and continuously guiding them. Such an explanation appeared in the Western literature after evolution in the idea of leadership. Respondents 3, 5, 7, 12 also advocated that there was a completely different understanding with initial definitions of leadership. Respondents added that when leadership came into a discussion of organizational literature, it used the definition required for the industrial era's success. Only respondent 6 thought that leadership or other social ideas are led by progressive cultures. Hence, their definition and understanding should be practiced. Respondent 6 elaborated further that organizational and social sciences were led by cultures that were more productive in the industrial age. Respondent 4, 13 explained that this could be because of a difference in language. Various languages have different nomenclatures for social constructs. That conveys the different meaning of social ideas. In the east, words chosen for leadership are more patriarchal and serving though such definitions appeared in Western literature in the late 80s. Respondents 8, 10, 14 elaborated that over the period of time it can be seen that Western hegemony has been exiting. West is showing the destination and the only path to be used to reach that destination. This is like ignoring all other avenues to understand that phenomenon. Respondents 9 and 15 considered that leadership is a universal phenomenon and all cultures may add their input to it. As the Earth is heading to be a global village, it will give a chance to all the cultures to add their values to it. Thus, leadership can learn from cultures across the planet and come up with a universal understanding of it. For the majority of respondents, the idea of leadership has different values and expectations. It was considered to be more service and follower-oriented. Leadership in the East since antiquity carried a lot of spiritual messages for followers.

Overall response of the participants was in the form of disagreement from an orthodox understanding of leadership. Most of the respondents explicitly differed with the definition of leadership as per Western expectations. Respondents expressed their differences due to language and meaning associated with leadership in their local language. Respondents considered leadership to be a responsibility rather than an esteemed position. Table 2 shows the process of theme emergence from the response of interviews. 
Table 2

The First Theme Related to Different Understanding of Leadership in the East

\begin{tabular}{|c|c|c|c|c|c|}
\hline Codes / Descriptors & $\begin{array}{l}\text { Frequency of } \\
\text { mention by } \\
\text { Respondents }\end{array}$ & $\begin{array}{l}\text { Raters' } \\
\text { reliability } \\
\text { for Sub- } \\
\text { themes }\end{array}$ & $\begin{array}{l}\text { Focused Codes / Sub- } \\
\text { themes }\end{array}$ & $\begin{array}{l}\text { Raters' } \\
\text { Reliability } \\
\text { for Themes }\end{array}$ & Themes \\
\hline $\begin{array}{l}\text { Eastern understanding of } \\
\text { leadership focused on serving } \\
\text { followers }\end{array}$ & $92 \%$ & \multirow[t]{2}{*}{$96 \%$} & \multirow[t]{2}{*}{$\begin{array}{l}\text { Eastern understanding } \\
\text { of leadership }\end{array}$} & & \multirow{7}{*}{$\begin{array}{l}\text { Eastern and Western } \\
\text { understanding of } \\
\text { leadership have basic } \\
\text { differences due to } \\
\text { numerous reasons } \\
\text { like language, degree } \\
\text { of industrial } \\
\text { advancement, and } \\
\text { values and } \\
\text { expectations attached } \\
\text { with leaders. }\end{array}$} \\
\hline $\begin{array}{l}\text { Eastern concept declared } \\
\text { leadership to be altruistic }\end{array}$ & $90 \%$ & & & & \\
\hline $\begin{array}{l}\text { Western } \quad \text { (capitalistic) } \\
\text { understanding of leadership } \\
\text { clashes with Eastern }\end{array}$ & $88 \%$ & \multirow[t]{2}{*}{$92 \%$} & \multirow[t]{2}{*}{$\begin{array}{l}\text { Western understanding } \\
\text { of leadership }\end{array}$} & & \\
\hline $\begin{array}{l}\text { Altruistic leadership was } \\
\text { discussed in the Western context } \\
\text { after the evolution }\end{array}$ & $92 \%$ & & & & \\
\hline $\begin{array}{l}\text { One of the major reasons forthe } \\
\text { difference in understanding was } \\
\text { a language }\end{array}$ & $96 \%$ & \multirow[t]{3}{*}{$92 \%$} & \multirow[t]{3}{*}{$\begin{array}{l}\text { Likely causes of } \\
\text { difference }\end{array}$} & \multirow{3}{*}{$90 \%$} & \\
\hline $\begin{array}{l}\text { West had the hegemony on the } \\
\text { concept of leadership, ignoring } \\
\text { all other conceptualizations }\end{array}$ & $88 \%$ & & & & \\
\hline $\begin{array}{l}\text { Only industrially advanced } \\
\text { nations seemed to lead the } \\
\text { concept of leadership }\end{array}$ & $90 \%$ & & & & \\
\hline
\end{tabular}

\section{Theme 2: Capitalistic Definition of Leadership in Business and Management}

As presented in Table 3, Respondent 1, 2, and 3 reflected that definition of leadership which appeared in the literature of Business and Management in the industrial era, was guided by earlier capitalistic motion. The same definition travelled through textbooks to students across the world. The same has been explored by Khan and Kohsul (2011) that capitalism or colonial theories limit the local wisdom and put boundaries around the indigenous thoughts. With the evolution in the definition of leadership still a gap exists in how leadership was considered to be in the East. Banerjee et al. (2008) have already explored the impacts of post-colonial Western capitalism and its domination of the Eastern world. Respondent4and13 explained that the context of leadership explains a lot about its understanding. Certainly, capitalism boosted the definition of leadership, which is result-oriented. Each good is transactional for the profits of the organization. Thus, as understood today in Eastern schools, leadership is only in the context of profit maximization and leading the people to more profits. Respondents 5, 7, and 11 also agree that leadership only talks about meeting the ends with only making people the vehicle when examined in business contexts. A leader from the earlier $20^{\text {th }}$ century only sees followers as the means to the end, and their welfare was kept secondary. Respondent 6 considers that business and management talks about profits and results. Hence, it has to be pragmatic. Pragmatism and transactional leadership helped modern organizations achieve wonders in their output and production. The rising demand of consumerism could not have been achieved by any other way. Leaders need to act as per the need of the organization. Respondent8, 9, and 14 elaborated the view that capitalism has been defining the tasks of leaders. Expectations of leaders were set by the market demand and transmitted to other parts of the world too. Thus, other parts of the world have learned from organizations that were achieving their results. Thus, success in production and innovation facilitated Western schools to spread its definitions in organizational and management schools. Respondent 10 and 15 had 
a view that the industrial era designed new work culture though the definition evolved, it still carries the message of a transaction on the cost of beings working for it. Respondents added that previous work cultures had different aims. As we know, leadership has been in the practice of religious and statesmen; however, the industrial era or the organizational culture demanded something new from the leader. Respondents quoted Marx and other existential scholars who were looking at the emergence of new work culture. Leaders were the ones who were regulating that work culture and helping that to be successful. Respondents highlighted that leadership proposed by the West or taught through Western text is more designed for the industrial era with capitalistic expectations. Thus, the established definition of leadership is not congruent with the values and cultures of the respondent's country.

Overall participants expressed their concern regarding the definition of leadership and how it is powered by capitalistic and industrial mindset. Most of the respondents viewed leadership as a tool to exploit resources for profit. As per Western literature, a leader is a profit-centric thinker for whom humanity can be a means to the end.

Table 3

The Second Theme Related to Capitalistic Definition of Leadership in Business and Management Capitalistic Definition of Leadership in Business and Management

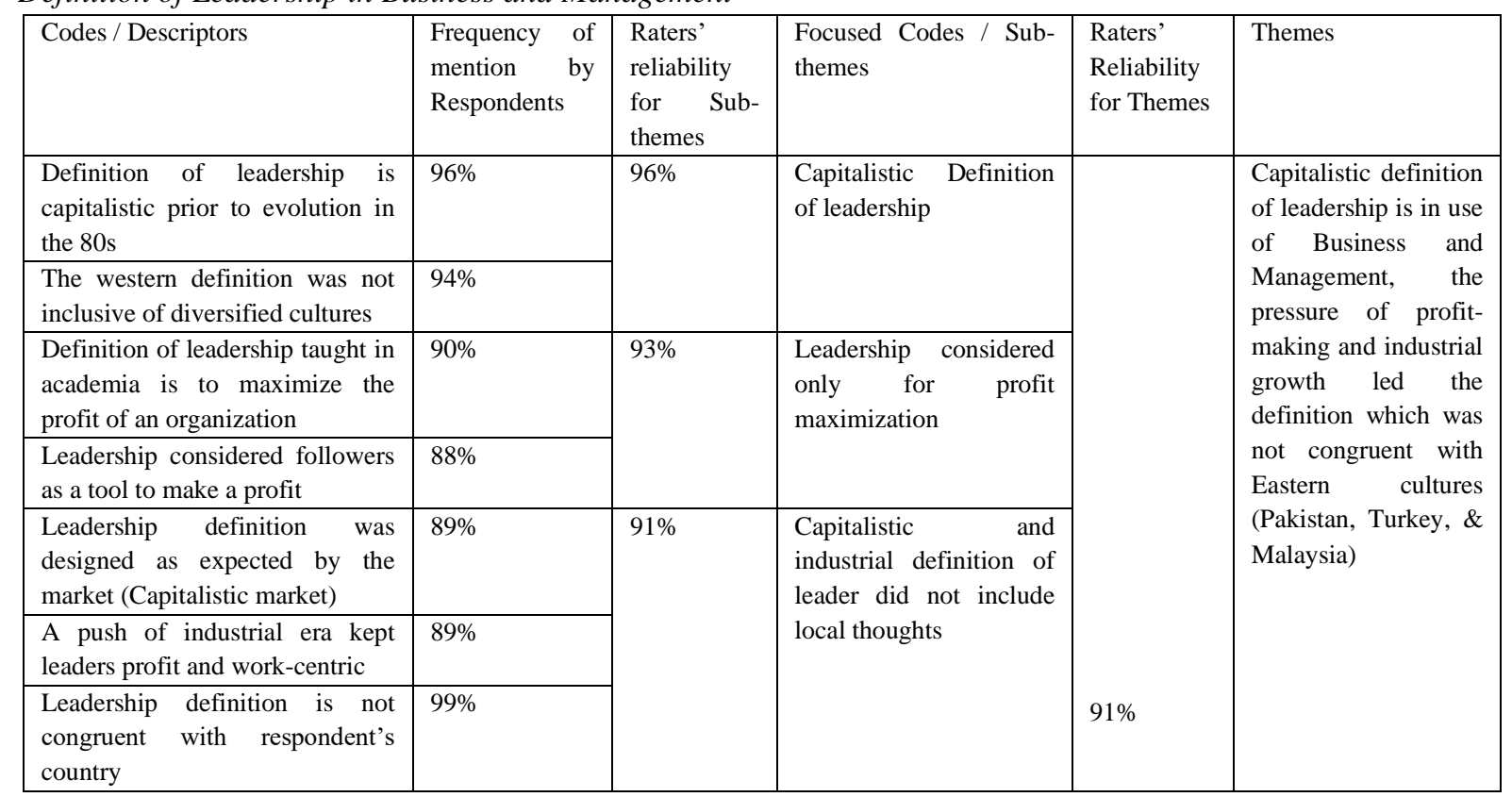

\section{Theme 3: Hegemony for Social Ideas}

As shown in Table 4, hegemony can be witnessed in ideas related to business and management. Hegemony is observed in the domination of Western thoughts educating other cultures and continents. Respondent 1 specifically quoted "white man's burden" and how it is assumed that other cultures are not educated enough to understand the modern world. Hence, theories of leadership, motivation, team building, etc. For Respondent 2 and15, this hegemony is visible in that scholars and practitioners have to look at Western theories for approval for every question. Disagreement or refutation, which had been the essence of learning, has been criticized and ignored when theories emerged from other schools/Eastern schools. Even they are accepted yet not incorporated seriously for practice. It is the case for inclusion for such works in courses taught worldwide. Respondent 3 and14 recorded his view regarding 
Orientalism, West or leading schools consider that oriental is nothing but romantic unscientific understanding of the world. Hence, it had its days which are over now. To progress, the understanding made in specific schools should be incorporated. This is a regular understanding of the phenomenon under study. Various theories or personalities would not be learned or deciphered as they emerge from cultures that are not successful these days. Respondent 4 traced the outline of the current discussion under the use of language. The current debate of hegemony exists in the real world, but language, particularly English, played a greater part. For Respondent, the idea of perfect man or leaders appeared more frequently in Indian texts but has not been added in standard text. India has a rich mythology, list of great poets and thinkers yet inclusion is not visible. Respondent 4 considered language as the tool of hegemony that has overtaken the world of academics and only theories from certain cultures are added in academic courses. Respondent 6 gave opposing views. Respondent considers knowledge as a universal phenomenon. Respondent supplemented the argument with historical evidence that there were times in history when the East guided the rest of the world; however, it is the other way around now. For the respondent, the West has shown remarkable progress in science and development since the industrial era. Respondent 6 concluded that in social science and idea like leadership, there are grey zones that needed to be addressed. Because ideas like leadership ultimately touch the values of the culture. Respondents 9 and 14 added in the earlier theme that all cultures had to put input into constructing social ideas. Leadership had to learn from all cultures. This hegemony is the part responsible for not having interesting theories coming from the East. However, we also see hegemony, which demands critical studies infield of management science and business studies. Respondents 7, 8, and 10 stressed the importance of fewer places where ideas from the East can be published. Even the published work is very less in number as compared to mainstream ideas.

Most of the participants responded that they had observed the growing hegemony of social ideas from the West over the period. The tool to colonize has changed, and oriental thinking has been eliminated from regular business and management text. Participants expressed concerns that oriental thought has been associated with non-productive romantic thinking over the period, which might not be suitable for business agility. Respondents urged that this assumption should change. 
Table 4

The Third Theme Related to Hegemony for Social Ideas

\begin{tabular}{|c|c|c|c|c|c|}
\hline Codes / Descriptors & $\begin{array}{l}\text { Frequency of } \\
\text { mention by } \\
\text { Respondents }\end{array}$ & $\begin{array}{l}\text { Raters' reliability } \\
\text { for Sub-themes }\end{array}$ & $\begin{array}{l}\text { Focused Codes / } \\
\text { Sub-themes }\end{array}$ & $\begin{array}{l}\text { Raters' } \\
\text { Reliability for } \\
\text { Themes }\end{array}$ & Themes \\
\hline $\begin{array}{l}\text { Hegemony in ideas of business and } \\
\text { management from West }\end{array}$ & $91 \%$ & \multirow[t]{2}{*}{$93 \%$} & \multirow[t]{2}{*}{$\begin{array}{l}\text { The hegemony of } \\
\text { ideas from West }\end{array}$} & \multirow{7}{*}{$93 \%$} & \multirow{7}{*}{$\begin{array}{l}\text { The } \\
\text { hegemony } \\
\text { of Social } \\
\text { Ideas from } \\
\text { West }\end{array}$} \\
\hline $\begin{array}{l}\text { Disagreements/refutations had not } \\
\text { been included in the dominant } \\
\text { literature }\end{array}$ & $92 \%$ & & & & \\
\hline $\begin{array}{l}\text { Eastern school of thought was } \\
\text { considered to be romantic yet } \\
\text { unscientific }\end{array}$ & $96 \%$ & \multirow[t]{2}{*}{$94 \%$} & \multirow{2}{*}{$\begin{array}{l}\text { Literature } \\
\text { business, } \\
\text { management and } \\
\text { leadership is not } \\
\text { inclusive }\end{array}$} & & \\
\hline $\begin{array}{l}\text { Eastern leaders and heroes were not } \\
\text { included in the scientific literature }\end{array}$ & $90 \%$ & & & & \\
\hline $\begin{array}{l}\text { The English language played a role } \\
\text { to colonize and hegemonies the } \\
\text { Western definition }\end{array}$ & $89 \%$ & \multirow[t]{3}{*}{$92 \%$} & \multirow{3}{*}{$\begin{array}{l}\text { English language } \\
\text { worked as barrier } \\
\text { for creating theories } \\
\text { and publishing them }\end{array}$} & & \\
\hline $\begin{array}{l}\text { Indigenous eastern thoughts receive } \\
\text { less acceptance by publication } \\
\text { houses }\end{array}$ & $91 \%$ & & & & \\
\hline $\begin{array}{l}\text { Cultures learn from each other, and } \\
\text { Eastern thought did not share } \\
\text { something valuable }\end{array}$ & $17 \%$ & & & & \\
\hline
\end{tabular}

\section{Theme 4: Incorporating Critical Management Studies for Leadership}

As demonstrated in Table 5, Respondent 1, 2, and 3 highlighted the need to encourage scholars to work on critical management studies in realm of leadership. Respondents had a view that in order to incorporate thoughts from unconventional schools, scholars should invest time to explore critical studies in domain of management studies. Respondent 2 emphasized that current social order cannot be corrected with increments rather a new social order should be proposed. They were becoming not part of the system but constructing or designing a new system. Respondent 3, however added a caveat that to do critical studies, scholars and researchers should be well equipped with traditional knowledge of leadership. Critical studies on leadership should not rise from ignorance but after a detailed analysis and incongruence of current academic understanding of leadership. Respondent 4 and13 also recorded their view that critical work is conducted in leadership already. However, those works of scholars were to assess the power and control dimensions of leadership. Yet a critical inclusion is required in the text of management and business, which invites thoughts from other schools of thought that stand on opposite poles of prevailing theories. Respondent 6 and15 also pointed out the role of critical studies in management science. Respondent 6 called attention to the fact that new theories will also be open for critic soon. Hence, current theories may be amended and adapted rather than opening a new road for research that may not deal with a destination. Respondent persisted that globalization demands universal works which may be localized as per the need of the society. Respondent pointed out terms like Glocalization which can be helpful given the current study. Respondent 6 stressed that with the emergence of globalization, we need theories of global scale that can be tailored to local needs. Instead, if we go into open avenues for local thoughts, then progress already made can be hindered. Responded 10 and15 also touched on the idea of critical studies in the domain of leadership. Respondent 10 further added that management practices are responsible for social transformation. Hence, theories of leadership or other important topics cannot be left without 
critical evaluation. One major school not only hegemonies its ideas but also blocks the alternate routes to development and progress. Management science is struggling in ethics, morality, and human development due to prevailing theories in the form of practices. Thus, scholars should decipher the power and subliminal structures in current theories of leadership. As leaders influence millions of lives, such a main subject cannot be left without critical management studies.

Overall, participants were urged to continue critical management studies in the realm of leadership. Critical studies for leadership and other areas of management science should be made part of the curriculum so students from local cultures can confidently critic Western theories. Participants expressed concern regarding the blind acceptance of Western theories in eastern cultures.

Table 5

The Third Theme Related to Incorporating Critical Management Studies for Leadership

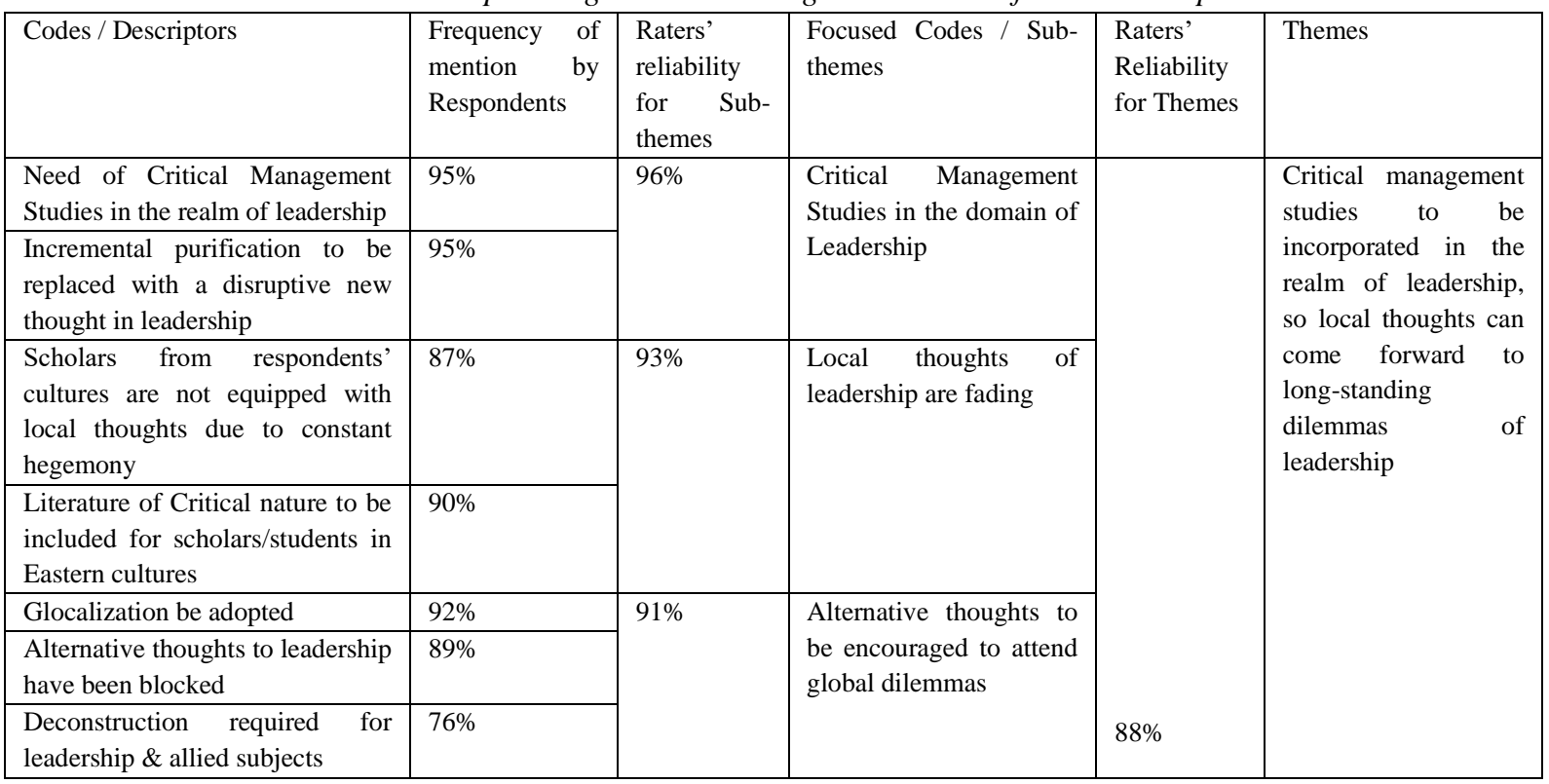

\section{Theme 5: Alternative Avenues to Address the Idea of Leadership}

All respondents replied to the main theme of the current research that thoughts and philosophies from the East and oriental root have not been incorporated in business and management literature. However, an idea like Servant leadership emerged out of the work of Herman Hesse titled "Journey to the East" (Hesse, 2003). As presented in Table 6, Respondent 1, 2, 11, and 14 reflected that case studies of local business leaders might be recorded and introduced to students. Then, a greater debate of incongruent leadership ideas can be introduced. Cases of successful businesses under local leaders may be archived and introduced for the study. This will reveal any practices that are not theoretically accurate or rational but do impart results for the leaders. This may further record that how indigenously leads have learned those practices. Respondent 3 and12 reported that family businesses in Pakistan and India have a history of unconventional practices yet giving positive results. Family businesses share leadership among family members, and still, no dispute is seen usually. However, chronicles of such works need to be complied with to unveil special practices of leadership. Respondent4, 5, 9, and 11 pointed out the work of poets from the East. They said there is a history of great thoughts coming from poetry, which has been visible even 
in the West. However, the East, specifically India and Pakistan, has many poets who wrote about perfect man and expectations from leaders. Respondent 5 talked about Chanakya's work Arthashastra which was one of the earliest idea about leadership i.e. Sage-King. Strangely no serious attempt has been made to record the work of indigenous philosophers stressed by respondent 5 .

However, Respondent1, 2, 3, 4, 9, and 10 talked about poet-philosopher Dr Muhammad Iqbal, who is considered to be the poet of the East. Respondent specifically quoted him as a polymath as his philosophical work has been used in sociology, economy, religion, law, Islamic law, psychology, and poetry. Respondent 2 recalled him as a scholar who has been reverted in Iran, Turkey, Pakistan, India, and Malaysia to critique Western philosophy and incorporate thoughts from the East. Respondent 2 highlighted that Iqbal had been an ardent reader of Western literature, which gave him the edge to write beyond Western models. Respondent 1 pointed out areas from where leaders can learn from the work of Iqbal specifically his idea of will and motivation, which was called Khudi. Secondly, his idea of intuition as the strongest form of wisdom can be useful for decision-makers. Respondent 3 and 4 precisely pointed out his idea of the perfect man as the most valuable contribution in the $20^{\text {th }}$ century. His idea of the perfect man has traits, which are rooted in the Eastern culture. Idea of his perfect man matches with the values observed specifically in Pakistan, Iran, Malaysia, and Turkey. Respondent 4 highlighted that Iqbal's perfect man has been under philosophical debate for decades now. Certainly, it is a powerful thought hence surviving. Subjects like Management and business should work on it. Respondent 9 recorded that Iqbal has so much to say about the perfect man as his poetry is human-centric. Thus, he also worked on a perfect idea of being which should lead the universe. Respondent 10 also recorded that Iqbal has been a source of inspiration for generations. Specifically, by motivating readers through his idea of the perfect man. In general, all respondents affirmed that in light of Feyerabendian philosophy, the poetry of Iqbal could guide us through to a new leadership model.

Respondents quoted various thinkers and poets who had been influential in eastern thought. However, they had not been introduced to business and management literature. Respondents from Turkey and Pakistan specifically quoted poet-philosopher "Iqbal" who wrote extensively in various fields of knowledge. While he was a critic of the Western thinking system, he also gave a solution and way out from these dilemmas. Respondent mentioned his idea of the perfect man, which can be one of the alternative ways of addressing the dilemma of ethical leadership. 
Table 6

The Third Theme Related to Alternative Avenues to Address the Idea of Leadership

\begin{tabular}{|c|c|c|c|c|c|}
\hline Codes / Descriptors & $\begin{array}{l}\text { Frequency of } \\
\text { mention by } \\
\text { Respondents }\end{array}$ & $\begin{array}{l}\text { Raters' } \\
\text { reliability } \\
\text { for Sub- } \\
\text { themes }\end{array}$ & $\begin{array}{l}\text { Focused Codes / Sub- } \\
\text { themes }\end{array}$ & $\begin{array}{l}\text { Raters' } \\
\text { Reliability } \\
\text { for Themes }\end{array}$ & Themes \\
\hline $\begin{array}{l}\text { Case studies of local leaders to } \\
\text { be developed }\end{array}$ & $91 \%$ & \multirow[t]{2}{*}{$90 \%$} & \multirow[t]{2}{*}{$\begin{array}{l}\text { Developing local studies } \\
\text { on leadership }\end{array}$} & & \multirow{5}{*}{$\begin{array}{l}\text { Archiving alternative } \\
\text { thoughts on } \\
\text { leadership, coming } \\
\text { from poetry, local } \\
\text { wisdom, and } \\
\text { indigenous business } \\
\text { leaders of the East. } \\
\text { Especially work of a } \\
\text { poet of the East i.e. } \\
\text { Iqbal, can be a new } \\
\text { insight into } \\
\text { leadership }\end{array}$} \\
\hline $\begin{array}{l}\text { Local management practices to } \\
\text { be archived }\end{array}$ & $89 \%$ & & & & \\
\hline $\begin{array}{l}\text { Thoughts of sages from the East } \\
\text { to be compiled for leadership }\end{array}$ & $90 \%$ & \multirow[t]{2}{*}{$89 \%$} & \multirow{2}{*}{$\begin{array}{l}\text { Archiving thoughts of } \\
\text { sages and poets on } \\
\text { leadership }\end{array}$} & & \\
\hline $\begin{array}{l}\text { Thoughts of Poets from East to } \\
\text { be compiled for leadership }\end{array}$ & $96 \%$ & & & & \\
\hline $\begin{array}{ll}\text { To encourage } & \text { alternative } \\
\text { thoughts to guide } & \text { leadership } \\
\text { from eastern cultures } & \end{array}$ & $86 \%$ & $88 \%$ & $\begin{array}{l}\text { Promote Alternative } \\
\text { thoughts on leadership }\end{array}$ & $90 \%$ & \\
\hline
\end{tabular}

\section{Variance in response due to Nationality of the respondents}

Respondents of the current study are from three different nationalities i.e. Pakistan, Turkey, \& Malaysia. No major variance was observed in the response of the participants. Apart from respondent number 6, all other respondents believed that leadership has a different understanding in the East; it is more like a giving phenomenon rather than ruling the followers. Respondents also added that due to differences in language, thoughts from their culture are not included in leadership literature. Respondents recommended critical studies for the phenomenon of leadership. However, respondent number 6 considered that in the global arena leading cultures define the constructs. For pragmatic reasons, leadership has to be transactional. However, the rest of the fourteen participants of the study believed that leadership in current literature is nurtured for capitalism and industrial growth; hence, it lacks empathy and morality for a reason.

\section{Discussion}

Literature and definition of leadership had been influenced by Eurocentric thoughts, making leadership theories peculiar and hedonistic to other cultures. Similarly, power is an inescapable feature of Western theories, recently a change has been observed in Western literature, but a survey of 1970 found 130 definitions of leadership having a significant role of power, influence the authority (Moten, 2011). A similar finding emerged from the current study. Leadership has a different understanding in the East; it is about serving others and reflecting altruistic behaviour.

Traditional perspective of business is only about profit-making, emphasis is on wealth creation, and the leader has to maximize this goal (Peredo \& Mclean, 2013). Peredo and Mclean (2013) studied the variance in the philosophy of indigenous entrepreneurs and traditional entrepreneurs. Indigenous leaders had a passion for serving, and traditional leaders considered wealth maximization the firm's key agenda. A similar difference was also observed in the current study. A theme emerged that the definition of leadership is not compatible with the values of Eastern culture.

Apart from profit-making, power is central to leadership in the West (Alvesson \& Spicer, 2012). Critical leadership studies are looking into the relationship of power structures of leadership construct. Respondents of the current study urged to promote such studies in 
Eastern culture, as indigenous scholars can add their value to deconstruct the myth of leadership.

Lastly, respondents had names of sages, scholars, and poets from their culture admired in history yet not conceptualized in business and management literature. It was not the scope of the study to identify the reasons why those thoughts have not been included in mainstream literature. A couple of respondents mentioned poet-philosopher Iqbal, who led the freedom movement of the sub-continent. One respondent even added that even Iranian culture reveres Iqbal's idea of a perfect man. Thus, indigenous structured thoughts on leadership need to be archived from eastern cultures. Table 7 succinctly presents the themes of the current study in comparison to mainstream Western literature on leadership.

Table 7

The Themes of the Current Study in Comparison to Mainstream Western Literature on Leadership

\begin{tabular}{|c|c|c|}
\hline Theme & Orthodox understanding in the Western text & Emerging Answers from the current Study \\
\hline $\begin{array}{l}\text { Different understanding } \\
\text { Leadership in East }\end{array}$ & $\begin{array}{l}\text { Mainstream leadership literature is leader centric } \\
\text { (not follower centric) and it is also powered by } \\
\text { the Western values. Leader itself is considered to } \\
\text { be high positioned power centric entity }\end{array}$ & $\begin{array}{l}\text { Leadership in the East has altruistic } \\
\text { assumptions. In Eastern cultures, it had been } \\
\text { about serving others. } \\
\text { The same has been highlighted in the study of } \\
\text { Sharma (2018) i.e. Selfish Gene Leadership }\end{array}$ \\
\hline $\begin{array}{l}\text { Capitalistic Definition of leadership } \\
\text { in Business and Management }\end{array}$ & $\begin{array}{l}\text { Money can only lead to happiness, and profits } \\
\text { should always stay centric to organizations for } \\
\text { growth (Jironet, 2010) }\end{array}$ & $\begin{array}{l}\text { Definition of leadership is not congruent with } \\
\text { values and cultures of Respondent's country } \\
\text { Traces of such thoughts are available in } \\
\text { studies like "The Hegemony of Western } \\
\text { Business Management Literature in Non- } \\
\text { Western Settings" (Whiteley, 1996) }\end{array}$ \\
\hline The hegemony of Social Ideas & $\begin{array}{l}\text { Best practices of management come from West } \\
\text { and eastern theories and practices to be replaced } \\
\text { with their (better) Western theory } \\
\text { A similar study was conducted by Mir et al. } \\
\text { (2008) }\end{array}$ & $\begin{array}{l}\text { Social ideas should be constructed around } \\
\text { local culture. Social ideas should have } \\
\text { productive thoughts from diversified cultures. }\end{array}$ \\
\hline $\begin{array}{l}\text { Incorporating Critical Management } \\
\text { Studies for Leadership }\end{array}$ & $\begin{array}{l}\text { The idea of leadership and other management } \\
\text { practices are universal, and Western industrial } \\
\text { success should be copied by other } \\
\text { cultures/nationalities }\end{array}$ & $\begin{array}{l}\text { Important to critically analyze the theories } \\
\text { coming from Western schools and } \\
\text { encouraging critical deconstruction of such } \\
\text { thoughts } \\
\text { The work of Learn month and Morrell } \\
\text { highlights the need for critical studies in } \\
\text { leadership and specifically to change the } \\
\text { language of leadership. Critical Leadership } \\
\text { Studies can address key questions of power } \\
\text { and inequality in the system (Collinson, } \\
\text { 2017) }\end{array}$ \\
\hline $\begin{array}{l}\text { Alternative avenues to address the } \\
\text { idea of Leadership }\end{array}$ & $\begin{array}{l}\text { Empirical studies with the proper theoretical } \\
\text { background can only pave the way to theory } \\
\text { development and to be made part of the } \\
\text { curriculum }\end{array}$ & $\begin{array}{l}\text { Theorizing thoughts of Eastern sages and } \\
\text { poets to attend to the big questions of } \\
\text { leadership. Specifically, the work of a poet of } \\
\text { East, i.e. Muhammad Iqbal, is to draw a new } \\
\text { leadership model that suits Eastern values. } \\
\text { Turnbull (2011) has already highlighted the } \\
\text { same. Beyond Western expectations, we can } \\
\text { find leadership wisdom to result in a more } \\
\text { responsible and sustainable world. } \\
\text { Vardoshvili (2019, October) considers } \\
\text { leadership as an offshoot of poetry and } \\
\text { fiction as poetry is nothing but another tool to } \\
\text { inspire masses and causing awakening }\end{array}$ \\
\hline
\end{tabular}

\section{Conclusion}

From the interviews conducted, it is evident that cultures may seek leadership models having synergy with their values. As results revealed, there is a different understanding of leadership 
in Eastern cultures. Hegemony has been witnessed in the past regarding social ideas and values pushed from the West. The findings highlight that a large gap exists to incorporate thoughts and philosophies from the East, specifically from Pakistan, Turkey, and Malaysia. The capitalistic school of thought more defines leadership in practice or thought. Thus, this needs a review. If critical studies are taken more frequently in these countries, then more avenues can be opened to address the dilemmas of management science. Traditional philosophy in these countries can be helpful to address the issues of leadership. One major name pointed out in the interview is Dr. Muhammad Iqbal. He was a poet-philosopher who wrote assertively about the role of mankind in the universe as the only active phenomenon. $\mathrm{He}$ also proposed his idea of the perfect man for society. This work can be integrated into the text of management science and business studies. As previously, West has been using the work of poets (Grisham, 2006) and already highlighted learning from work of fiction coming from the East (Greenleaf, 1997). Similarly, the work of Iqbal can provide great insight to scholars and researchers working in the realm of leadership.

\section{References}

Adler, N. J. (1983). A typology of management studies involving culture. Journal of International Business Studies, 14(2), $29-47$.

Adler, P. S., Forbes, L. C., \& Willmott, H. (2007). 3 Critical management studies. Academy of Management Annals, 1(1), $119-179$.

Alvesson, M., \& Spicer, A. (2012). Critical leadership studies: The case for critical performativity. Human Relations, 65(3), $367-390$.

Alzadjali, B. (2009). Japanese management techniques. GRIN Verlag

Anderson, H. J., Baur, J. E., Griffith, J. A., \& Buckley, M. R. (2017). What works for you may not work for (Gen) Me: Limitations of present leadership theories for the new generation. The Leadership Quarterly, 28(1), 245-260.

Antonakis, J., \& Day, D. (2017). The nature of leadership. Los Angeles: Sage Publications.

Axelrod, A. (2010). Gandhi, CEO: 14 Principles to Guide \& Inspire Modern Leaders. Sterling.

Banerjee, S. B., \& Prasad, A. (2008). Introduction to the Special Issue on "Critical Reflections on Management and Organizations: A Postcolonial Perspective". Critical Perspectives on International Business, 4(2/3): 90-98.

Barkema, H. G., Chen, X. P., George, G., Luo, Y., \& Tsui, A. S. (2015). West meets East: New concepts and theories. Academy of Management Journal, 58(2), 460.

Bass, B. M. (2008). The Bass handbook of leadership: Theory, research, and management applications. Free Press.

Bass, B. M., \& Riggio, R. E. (2006). Transformational leadership. Mahwah, NJ: Erlbaum

Beechler, S., \& Yang, J. Z. (1994). The transfer of Japanese-style management to American subsidiaries: Constraints, and competencies. Journal of International Business Studies, 25(3), 467-491.

Bhatti, O. K., Aslam, U. S., Hassan, A., \& Sulaiman, M. (2016). Employee motivation an Islamic perspective. Humanomics, 32(1), 33-47. https://doi.org/10.1108/H-10-2015-0066

Blunt, P., \& Jones, M. L. (1997). Exploring the limits of Western leadership theory in East Asia and Africa. Personnel Review, 26(1/2), 6-23.

Boddy, C. R. (2011). The corporate psychopaths theory of the global financial crisis. Journal of Business Ethics, 102(2), $255-259$.

Cappelli, P., Singh, H., Singh, J., \& Useem, M. (2010). The India way: How India's top business leaders are revolutionizing

management. Harvard Business Press.

Carlyle, T. (1993). On heroes, hero-worship, and the heroic in history (Vol. 1). University of California Press. 
Chen, M. J., \& Miller, D. (2011). The relational perspective as a business mindset: Managerial implications for East and West. Academy of Management Perspectives, 25(3), 6-18.

Coetzer, M. F. (2020, July 14). The Rise of Servant Organizations. Forbes.com. Retrieved from https://www.forbes.com/sites/forbescoachescouncil/2020/07/14/the-rise-of-servant-organizations/?sh=665582e953b5

Colbert, A. E., Judge, T. A., Choi, D., \& Wang, G. (2012). Assessing the trait theory of leadership using self and observer ratings of personality: The mediating role of contributions to group success. The Leadership Quarterly, 23(4), 670-685.

Collinson, D. (2017). Critical leadership studies: A response to Learmonth and Morrell. Leadership, 13(3), $272-284$.

Creswell, J. W. (2014). Qualitative, quantitative and mixed methods approaches. Sage

Daft, R. L. (2014). The leadership experience. Cengage Learning.

Day, D. V. (Ed.). (2014). The Oxford handbook of leadership and organizations. Oxford Library of Psychology.

Day, D. V., \& Antonakis, J. (2012). Leadership: Past, present, and future. The nature of leadership, 2, 3-25.

Day, D. V., Fleenor, J. W., Atwater, L. E., Sturm, R. E., \& McKee, R. A. (2014). Advances in leader and leadership development: A review of 25 years of research and theory. The Leadership Quarterly, 25(1), 63-82.

Day, D. V., \& Zaccaro, S. J. (2007). Leadership: A critical historical analysis of the influence of leader traits. Historical Perspectives in Industrial and Organizational Psychology, 383-405.

Deloitte, B. (2016). Global human capital trends 2016, the new organization: different by design. Retrieved from https://www2. deloitte. com/content/dam/Deloitte/at/Documents/human-capital/hc-trends-2015. pdf

Den Hartog, D.N., \&Dickson, M.W. (2004) Leadership and culture. In J. Antonakis, A. T. Cianciolo, \& R. J. Sternberg (Eds.), The Nature of Leadership (PP. 249-278). London: Sage.

Dickson, M. W., Castaño, N., Magomaeva, A., \& Den Hartog, D. N. (2012). Conceptualizing leadership across cultures. Journal of World Business, 47(4), 483-492.

Dinh, J. E., \& Lord, R. G. (2012). Implications of dispositional and process views of traits for individual difference research in leadership. The Leadership Quarterly, 23(4), 651-669.

Dinh, J. E., Lord, R. G., Gardner, W. L., Meuser, J. D., Liden, R. C., \& Hu, J. (2014). Leadership theory and research in the new millennium: Current theoretical trends and changing perspectives. The Leadership Quarterly, 25(1), 36-62.

England, G. W. (1983). Japanese and American management: Theory Z and beyond. Journal of International Business Studies, 14(2), 131-142.

Fiedler, F. E. (2006). The contingency model: H theory of leadership effectiveness. Small Groups: Key Readings, 369.

Feyerabend, P. (1995). Killing time: The autobiography of Paul Feyerabend. Chicago, IL: University of Chicago Press.

Gandolfi, F., \& Stone, S. (2018). Leadership, leadership styles, and servant leadership. Journal of Management Research, 18(4), 261-269.

Gardner, W. L., Lowe, K. B., Moss, T. W., Mahoney, K. T., \& Cogliser, C. C. (2010). Scholarly leadership of the study of leadership: A review of The Leadership Quarterly's second decade, 2000-2009. The Leadership Quarterly, 21(6), 922958.

Geeraert, G. (2018, March 12). Learning about different cultures is shaking the foundations of psychology. Retrieved from www.weforum.org

Gehring, D. R. (2007). Applying traits theory of leadership to project management. Project Management Journal, 38(1), 44-54.

Giles, S. (2016, March 15). The most important leadership competencies, according to leaders around the world. Harvard Business Review, 2-6. Retrieved from https://hbr.org/2016/03/the-most-important-leadershipcompetencies-according-toleadersaround-the-world.

Gordon, A., \& Yukl, G. (2004). The future of leadership research: Challenges and opportunities. German Journal of Human Resource Management, 18(3), 359-365.

Greenleaf, R. K. (1978, November). The leadership crisis: A message for college and university faculty. Humanitas: Journal of the Institute of Man, 14(3), Pittsburg, PA: Dusquesne University Press.

Greenleaf, R. K. (1997). The servant as leader. University of Notre Dame Press.

Greenleaf, R. (2007). The servant as leader. In Corporate ethics and corporate governance (pp. 79-85). Springer, Berlin, Heidelberg. 
Grisham, T. (2006). Metaphor, poetry, storytelling and cross-cultural leadership. Management Decision, 44(4), 486-503.

Harkiolakis, N., Halkias, D., \& Komodromos, M. (2017). A historical view of leadership prototypes: Looking backward to move forward. International Leadership Journal, $9(2)$.

Henrich, J., Heine, S. J., \& Norenzayan, A. (2010). Most people are not WEIRD. Nature, 466(7302), 29.

Hesse, H. (2003). The journey to the east: A novel. Macmillan.

Hofstede, G. (1980). Motivation, leadership, and organization: Do American theories apply abroad? Organizational Dynamics, 9(1), 42-63.

Hofstede, G. (1993). Cultural constraints in management theories. Academy of Management Perspectives, 7(1), 81-94.

Hofstede, G., Hofstede, G. J., \& Minkov, M. (2010). Cultures and organizations: Software of the mind. Revised and expanded.New York: McGraw-Hill.

House, R., Javidan, M., Hanges, P., \& Dorfman, P. (2002). Understanding cultures and implicit leadership theories across the globe: an introduction to project GLOBE. Journal of World Business, 37(1), 3-10.

House, R. J., Hanges, P. J., Javidan, M., Dorfman, P. W., \& Gupta, V. (Eds.). (2004). Culture, leadership, and organizations: The GLOBE study of 62 societies. Sage publications.

Hoch, J. E., Bommer, W. H., Dulebohn, J. H., \& Wu, D. (2018). Do ethical, authentic, and servant leadership explain variance above and beyond transformational leadership? A meta-analysis. Journal of Management, 44(2), 501-529.

Hunt, J. G., \& Dodge, G. E. (2000). Leadership déjà vu all over again. The Leadership Quarterly, 11(4), 435-458.

Ilies, R., Nahrgang, J. D., \& Morgeson, F. P. (2007). Leader-member exchange and citizenship behaviors: A metaanalysis. Journal of Applied Psychology, 92(1), 269.

Iordanoglou, D., Tsakarestou, B., Tsene, L., Ioannidis, K., \& Leandros, N. (2014). The development of an innovative leadership training programme for European young professionals in times of crisis. Procedia-Social and Behavioral Sciences, 156, 102-105.

Jironet, K. (2010). Female leadership: Management, Jungian psychology, spirituality and the global journey through purgatory. Routledge.

Khan, F. R., \& Koshul, B. B. (2011). Lenin in Allah's court: Iqbal's critique of Western capitalism and the opening up of the postcolonial imagination in critical management studies. Organization, 18(3), 303-322.

Kiker, D. S., Callahan, J. S., \& Kiker, M. B. (2019). Exploring the boundaries of servant leadership: A meta-analysis of the main and moderating effects of servant leadership on behavioral and affective outcomes. Journal of Managerial Issues, 31(2), 172-117.

Kuckartz, U. (2014). Qualitative text analysis: A guide to methods, practice and using software. Sage.

Law, K. A., Kevin, L. L. T., Low, Y. S., \& Fei, T. L. K. (2016). Sun Zi Art of War and Chinese corporate leadership: An inductive analysis. Australian Journal of Basic and Applied Sciences, 10(1), 48-57.

Li, A., McCauley, K. D., \& Shaffer, J. A. (2017). The influence of leadership behavior on employee work-family outcomes: A review and research agenda. Human Resource Management Review, 27(3), 458-472.

Lilienfeld, S. O., \& Waldman, I. D. (Eds.). (2017). Psychological science under scrutiny: Recent challenges and proposed solutions. John Wiley \& Sons.

Lowe, K., Avolio, B., \& Dumdum, U. (2013). Transformational and charismatic leadership: The road ahead. Leadership and Management, 5, 71-75.

Messick, D. M., \& Kramer, R. M. (Eds.). (2004). The psychology of leadership: New perspectives and research. Psychology Press.

Metcalf, L., \& Benn, S. (2013). Leadership for sustainability: An evolution of leadership ability. Journal of Business Ethics, 112(3), 369-384.

Mir, R., Banerjee, S. B., \& Mir, A. (2008). Hegemony and its discontents: A critical analysis of organizational knowledge transfer. Critical Perspectives on International Business, (2/3), 203-227. https://doi.org/10.1108/17422040810869990

Mitchell, K. (2020). The human cost of unresolved research dilemmas in psychopathy, machiavellianism, and narcissism. Working paper. Retrieved from https://www.researchgate.net/profile/Karen-Mitchell22/publication/351749874_The_Human_Cost_of_Unresolved_Research_Dilemmas_in_Psychopathy_Machiavellianism _and_Narcissism_Working_Paper_December_2020/links/60a7b947299bf1031fbae031/The-Human-Cost-of-UnresolvedResearch-Dilemmas-in-Psychopathy-Machiavellianism-and-Narcissism-Working-Paper-December-2020.pdf

Mohsen, N. R. M. (2007). Leadership from the Quran, operationalization of concepts and empirical analysis: Relationship between Taqwa, trust and business leadership effectiveness (Unpublished doctoral dissertation). Universiti Sains Malaysia, Kuala Lumpur, Malaysia. 
Moten, A. R. (2011). Leadership in the West and the Islamic world: A comparative analysis. World Applied Sciences Journal, 15(3), 339-349.

Munshi, S. (2010). Learning leadership: Lessons from Mahatma Gandhi. Asian Journal of Social Science, 38(1), 37-45.

Myers, M. D. (2013). Qualitative research in business and management. Sage.

Nayak, A. K. (2018). Effective leadership traits from Bhagavad Gita. International Journal of Indian Culture and Business

Management, 16(1), 1-18.

Neale, P. (2020, May 26). Why Servant Leadership Is More Important Than Ever. Forbes.com. Retrieved formhttps://www.forbes.com/sites/forbescoachescouncil/2020/05/26/why-servant-leadership-is-more-important-thanever/?sh=4ca4c6c 82861

Neubert, M. J., Hunter, E. M., \& Tolentino, R. C. (2016). A servant leader and their stakeholders: When does organizational structure enhance a leader's influence? The Leadership Quarterly, 27(6), 896-910.

Northouse, P. G. (2018). Leadership: Theory and practice. Sage publications.

Ogbonna, E., \& Harris, L. C. (2000). Leadership style, organizational culture and performance: empirical evidence from UK companies. International Journal of Human Resource Management, 11(4), 766-788.

Peredo, A. M., \& McLean, M. (2013). Indigenous development and the cultural captivity of entrepreneurship. Business andSociety, 52(4), 592-620.

Porter, M. E., Takeuchi, H., \& Sakakibara, M. (2000). Can Japan Compete? London: Macmillan.

Prastacos, G. P., Wang, F., \& Soderquist, K. E. (Eds.). (2013). Leadership through the classics: learning management and leadership from ancient east and West philosophy. Springer Science and Business Media.

Rosenbach, W. E. (2018). Contemporary issues in leadership. Routledge.

Selvarajah, C., Meyer, D., Sukunesan, S., \& Venkatapathy, R. (2014). Rise of the Indian firm: Understanding leadership in Indian organizations. In T. S. Chan, \& G. Cui (Eds), The rise of Asian firms (pp. 91-119). Palgrave Macmillan, London.

Sharma, S. (2018). From selfish gene leadership to cosmic gene leadership: Need for spirituality and mysticism in contemporary socio-political discourse. Available at SSRN 3121574.

Silverthorne, S. (2010). Mindful leadership: When east meets West. Harvard Business School Working Knowledge.

Sloan, M. (2016). Sun Tzu \& Machiavelli success and leadership principles: Based on the classics the art of war and the prince. CreateSpace Independent Publishing Platform

Spears, L. C. (2010). Character and servant leadership: Ten characteristics of effective, caring leaders. The journal of Virtues and Leadership, 1(1), 25-30.

Spector, B. A. (2016). Carlyle, Freud, and the great man theory more fully considered. Leadership, 12(2), 250-260.

Stogdill, R. M. (1974). Handbook of leadership: A survey of theory and research. New York, NY, US: Free Press.

Stogdill, R. M. (1975, August). The evolution of leadership theory. Academy of Management, 1975(1), 4-6.

Storey, J. (2016). Changing theories of leadership and leadership development. In Leadership in Organizations (pp. 17-41). Routledge.

Storz, M. L. (1999). Malay and chinese values underlying the malaysian business culture. International Journal of Intercultural Relations, 23(1), 117-131. http://dx.doi.org/10.1016/S0147-1767(98)00028-5

Sulaiman, M., Mohsen, M. R. N., \& Kamil, N. M. (2013). The role of spirituality and responsibility on business leadership effectiveness: An empirical analysis in the republic of Yemen. Paper presented at the 3rd Int. Management Conference. Bandung, Indonesia

Thompson, G., \& Glas $\varnothing$, L. (2018). Situational leadership theory: a test from a leader-follower congruence approach. Leadership and Organization Development Journal.39(5), 574-591. https://doi.org/10.1108/LODJ-01-20180050

Tucker, B. (2013). Leadership at the crossroads. WestBow Press.

Turnbull, S. (2011). Worldly leadership: Challenging the hegemony of Western business education. Journal of Global Responsibility, 2(2), 170-187.

Van Seters, D. A., \& Field, R. H. (1990). The evolution of leadership theory. Journal of Organizational Change Management, 3(3), 29-45.

Vardoshvili, E. (2019, October). Leadership and poetry: common tendencies in works of Georgian and European leader poets. Proceedings of the 4th International Conference of Social, Business and Academic Leadership (ICSBAL2019), 1st edn, Atlantis Press. 
Wang, F. (2017). Social justice leadership and The Art of War. Critical Studies in Education, 1-15.

Wang, A. C., Chiang, J. T. J., Chou, W. J., \& Cheng, B. S. (2017). One definition, different manifestations: Investigating ethical leadership in the Chinese context. Asia Pacific Journal of Management, 1-31.

Wheatley, M. (2011). Leadership and the new science: Discovering order in a chaotic world. ReadHowYouWant.com.

Whiteley, A. M. (1996). The hegemony of Western business management literature in non-Western settings: A Hong Kong study. Journal of Teaching in International Business, 7(4), 65-89.

Winston, B. E. (2018). Leadership style as an outcome of motive: A contingency 'state 'rather than 'trait' concept. Biblical Principles of Leading and Managing Employees, 7-14).

Wyatt, M., \& Silvester, J. (2018). Do voters get it right? A test of the ascription-actuality trait theory of leadership with political elites. The Leadership Quarterly, 29(5), 609-621.

Zaccaro, S. J. (2014). Leadership memes: From ancient history and literature to twenty-first century theory and research. The Oxford handbook of leadership and organizations, 13-39.

Zhang, X., Fu, P., Xi, Y., Li, L., Xu, L., Cao, C., ...\& Ge, J. (2012). Understanding indigenous leadership research: Explication and Chinese examples. The Leadership Quarterly, 23(6), 1063-1079.

\section{Acknowledgements}

Not applicable.

\section{Disclosure Statement}

No potential conflict of interest was reported by the authors.

\section{Funding Acknowledgements}

\section{Not applicable.}

\section{Open Access}

The International Journal of Organizational Leadership publishes open access articles under the terms of the Creative Commons Attribution (CC BY) License, which permits use, distribution, and reproduction in any medium, provided the original work is properly cited. 